\title{
Stories and Metaphors: Talking about the Past in a Psychotherapy Group for People with Dementia
}

\author{
RIK GHESTON*
}

\section{ABSTRACT}

Social constructionist approaches to the talk of older adults diagnosed as suffering from a dementing illness have emphasised the importance of analysing such talk in terms of its social function. Drawing on this work together with the increasing clinical impetus towards the development of psychotherapy in this area, this paper examines two sequences of stories produced during a psychotherapy group. These stories are seen as having two related functions: first, they enable individuals to explore the significance of their experiences and thus, it is argued, act as metaphors for the personal experience of having a dementing illness; and secondly they act as a means of creating a series of social identities. As such they serve as explanations of 'what it is to lose one's mind' (Sutton r994).

\section{KEY WORDS - Metaphor, dementia, Alzheimer's Disease,} psychotherapy, narrative, story-telling.

\section{Introduction}

Social psychological concepts of the function, value and significance of the talk of older people about the past have changed significantly over the last thirty years. From being associated with the advent of senility, and consequently discouraged, reminiscence has become repositioned as an activity that is involved in the establishment of psychological integrity through formal systems of 'therapy' (Coleman I994). Part of

* School of Social Sciences, University of Bath, Bath BA2 7AY, U.K. 
this continuing reinterpretation of reminiscence has come to be viewed as having both personal and social value (Buchanan and Middleton r994). Thus, despite cultural and clinical changes in theorising, reminiscence has continued to be an important area for practitioners and researchers (Buchanan and Middleton i 993).

The social nature of such reminiscences or talk about the past produced by people with Alzheimer's disease or other forms of dementia have been explored recently in two separate ways. First, Kitwood has detailed the role played by what he has described as 'the malignant social psychology' surrounding the individual who has been diagnosed as suffering from dementia. This role is instrumental in the further breakdown of that person's sense of self or 'personhood' (e.g. Kitwood I993, I990 b; Kitwood and Bredin I992). The individual is subject to a dual attack: from the internal onslaught to their neurological integrity by the disease process; and from the outside, for instance as their views are not taken seriously or they are treated as if they were children. Kitwood (rg90a) has contrasted 'unattended' dementia, when others are insensitive, uncaring or neglectful, with the possibility of truly therapeutic care, including psychotherapy. In this, one of the main tasks of the therapist is to 'hold' the person with dementia, to contain their emotional trauma and to allow a space for personal renewal through talk and other forms of exploration.

The second way in which the talk of older people with a dementing illness has been examined draws on a social constructionist perspective. In brief, this involves rejecting the taken-for-granted view of talking as a neutral form of expression which reflects the operation of internal structures such as a 'memory store' (Shotter I986). Instead different types of talking are seen as being shaped by the different functions that talk is meant to achieve. In particular language is used to represent or to understand the world and to co-ordinate diverse social activity (Shotter I 993). Thus, talk can be used to create a sense of shared social identity, give experiences shape and structure or act to move others towards the construction of the world that is being represented.

This paradigmatic shift in focus has begun to permeate analyses of the linguistic culture surrounding older people and into research focusing on the talk of people with Alzheimer's Disease. Buchanan and Middleton ( I 995), for instance, have suggested that talk about the past within a group setting operates to create a sense of shared identity. van Langenhove and Harré (I993) suggest that the significance of reminiscence lies in the way in which personal identity and selfhood are manifested in discursive practices such as the telling of lives. Similarly Sabat and Harré have examined the spoken communications of two 
individuals in advanced stages of Alzheimer's disease. They suggest that the use by these two people of first person indexicals ('I', 'me', 'mine' etc.) is evidence that self or 'personal identity remains intact far beyond the disintegration of many cognitive and motor functions' (1992:452). Sabat and Harré argue that these socially and publicly presented selves can be lost, not directly as a result of the disease process itself, but rather indirectly due to the restricted range of opportunities available to individuals to establish their identity through talk.

At the same time that writings drawing on ideas from social psychology have emphasised the importance of the immediate social context in the establishment of identity, so there has been increasing interest in working with individuals suffering from a dementing illness in a psychotherapeutic manner (e.g. Verwoerdt I 98 I ; Haight and Bahr I 984; Kitwood r $990 a$; Mills and Coleman r 994). Of these approaches the best known and most frequently described has been Validation Therapy (e.g. Babbins Ig88; Bleathman and Morton I988, ig9 I, I 992 ; Feil I 990, I 992, I 993). In addition Sutton (I 994) and Kitwood ( $1990 a$ ) have drawn attention to the frequently metaphorical nature of the talk of older people with dementia. Similarly Stokes and Goudie ( I990) suggest that the sometimes apparently confused talk of people with dementia represents attempts to make sense of the 'here-and-now' or are forlorn expressions of need. Alongside this increased interest in psychotherapy has been a growing recognition of the need to involve users in making decisions about their lives (Sperlinger and McAuslane I 994; Sutton and Fincham I 994) and to provide support groups (e.g. Yale i99 I).

\section{Narrative psychology and psychotherapy}

Social constructionist and psychotherapeutic approaches position talk about the past as occurring within related contexts: the immediate social context within which the talk is produced; and the more general context of a life history marked in its later stages by the personal and social experience of dementia. Talk about the past is therefore examined in terms of functioning, either to establish a social identity or as a way of exploring, and hence communicating, something of the experience of having a progressive memory loss.

In many ways, of course, these perspectives towards talk about the past overlap; creating an identity through talk could be seen as inherently therapeutic especially when that identity or personhood is threatened. Indeed social constructionist analyses of psychotherapy are 
becoming increasingly influential amongst clinicians. These stress the critical role of stories and story-telling within psychotherapy. Thus, Mair ( I g88) has described the integral role of the story in our lives, that the stories we tell and those we hear, tend to become the stories we live. Similarly, Gergen and Kaye ( I 992) view story telling as the central task of psychotherapy:

When people seek psychotherapy they have a story to tell. It is frequently the troubled, bewildered, hurt, or angry story of a life or relationship now spoiled. For many it is a story of a calamitous event conspiring against their sense of well being... For others the story may concern unseen and mysterious forces insinuating themselves into life's organized sequences, disrupting and destroying. And for others still it is as if, under the illusion of knowing how the world is or ought to be, they have somehow bumped up against trouble for which their favored (sic) account has not prepared them... (p. I66)

It is through the self-narrative, the story that we tell ourselves, that the ' $I$ ', the author, creates a story in which the 'me' is the protagonist and is able to act out roles. The self as the author is able both to imagine the future and to reconstruct the past. This is a process through which experiences which fall outside the self narrative are integrated into it, in which the unfamiliar is made familiar (Sarbin I986). Within these self-narratives, metaphors are deployed as an act of sense-making. Often our experiences are so complex and vague that they can only be expressed meaningfully through metaphors (Lakoff and Johnson i 980). For instance, when a novel situation is encountered for which no existing class or category of explanation is available, the experience is unintelligible or unassimilated. The recognition of a partial similarity between two events allows a basis for an analogy to be drawn, and if this is to be expressed through talk, then the partial similarity is expressed through metaphor (Sarbin I986).

Social constructionist conceptions of psychotherapy thus involve the psychotherapist moving away from interpreting the utterances of the client in terms of hypothesised internal entities such as schemas, unconscious processes and the like. Instead, the role of the therapist has been variously described as acting like a 'friendly editor' (Hoffman I988) helping the client to rewrite their self-narrative, or as leaving a space of 'not knowing' within which clients can begin to create themselves afresh (Anderson and Goolishan I992).

Self-narratives and stories can operate both as a means of communication and as a focus for exploration. They can permit a rich world, a place of re-memberance, a re-creation of people, ideas and images so positioned and constructed that they lend a new shape and form to the present. The creation of a story permits a world in which 
present dilemmas, uncertainties and hopes can be lived through. For this to be effective as a strategy for living, then enough stories, a large enough range of life enhancing rather than life restricting stories (Viney i993) need to be available to be told, capable of being flexibly interpreted:

Every story speaks of a world (or a self/world relationship). The world is hidden in the folds of the story and, to a degree, becomes available as the story unfolds. The self/world is difficult to read since the story speaks from it and through it and not generally about it. Stories assume and speak from their worlds. The facts - the kinds of facts - they allow are woven in their particular and mostly unspecified webs. (Mair i 988: 1 27)

The telling of stories in old age has been positioned as having social as well as personal value. For instance, the role of elders within a society in the transmission of information from one generation to the next is well documented. Thus Goleman (I994) cites Gutmann (I987) who describes how older people may be more effective as communicators of past events, how their dialogue focuses on talk about events when they were between fifteen and thirty and how this talk may fulfill a biological role within society, contributing to its welfare and survival by passing down experiences and knowledge. This process of recreating the past as a means of understanding the present is not restricted to the narrative story-telling of individuals. Museums, memorial services and other socially sanctioned forms of remembering serve as the structures through which shred myths can be developed (Radley i990).

\section{Data resources}

The data that is examined in this paper is taken from a psychotherapy group run in a psychogeriatric Day Hospital. The group involved five clients of the Day Hospital, was co-lead by three mental health professionals (two psychologists and one nurse) and met for eight weekly sessions. Each session was loosely organised around the discussion of a particular theme. These themes began with what were intended to be quite neutral topics, after which they then developed into exploring issues that were felt likely to be of significance for group members (e.g. experiences of loss, independence and dependency). The role of the group leaders involved a number of elements in addition to the typical role of leaders in therapy groups generally (e.g. Yalom I975), in particular acting as a group 'memory' by reminding individuals what had been said.

This paper focuses on some of the stories told by two members of the 
group: Roy, a 74-year-old man who had recently moved into the area and who was cared for by his step-daughter; and Daphne, a 78-yearold lady who was looked after by her daughter. Both Roy and Daphne had been given a diagnosis of Dementia of the Alzheimer's type within the previous year before the group was started. In the time since this work was completed (at the time of writing, just over a year) Roy has moved to a Nursing Home and his ability to communicate has much deteriorated. Daphne has begun to attend the local psychogeriatric hospital for regular respite visits although within herself she seems to be in much the same spirits as at the time of the group.

\section{Analysis of material}

It is not the purpose of this paper to give a full account of the nature of the groups from which these extracts have been taken. Rather the focus here is to identify the meaning and the function of the talk produced by two members of the group, Roy and Daphne. It will be argued that these stories act in two ways. First, particular remembered experiences recounted in the form of stories come to act as metaphors through which individuals are able to explore their experiences. Secondly, this talk about the past acts as a resource through which individuals can create a diversity of identities by positioning themselves as narrator in relation to a remembered past of previous experiences, struggles and endeavours.

Narrative psychology does not simply involve a different means of constructing the talk that individuals produce, it also has implications for the methodological analysis of such talk. One particular danger involved in such an analysis concerns the imposition of categories developed by the researcher upon the data. Literary criticism refers to this as 'reception theory', in that the hearer inevitably brings certain interpretations to the data. Consequently, it is important that such interpretations that are made arise from the data rather than being forced upon it: that, as far as possible, the categories that are used are those of the participants rather than the analyst.

A fundamental issue therefore for any analysis involves the need to place talk within the context within which it is produced (Sarbin I 986) so that the creation of meaning can be understood as a social activity, a product of everyday social interaction. Part of the analysis that has been adopted here concerns the need to locate the stories produced by group participants within a series of related contexts. This includes both the talk produced before and after the particular stories that are 
being considered, as well as other talk that, it will be argued, is related to these stories, and which is produced within the psychotherapy session as a whole. Finally, these stories need to be understood as being produced by people who are experiencing difficulties imposed on their lives by the illness of dementia itself. Consequently quite extensive and detailed transcriptions of the stories that are the focus for analysis have been provided. Similarly, the analysis also draws upon comments made by group participants about the function and significance of the stories that they have told.

As a consequence of the complexity of these methodological issues there is no clear agreement, even within discourse analysis about how the analysis of text should proceed. However, regardless of orientation much time is spent reading and re-reading the text, discussing with colleagues why and how a particular effect is created (Harper i 994). It is an open and interactive procedure which tends not to involve a list of techniques that can be applied to the analysis of text, but rather a framework within which the function, and hence the consequences, of the talk can be represented.

Within such a broad framework, a number of stages can nevertheless be identified (Potter and Wetherell I 987). Video recordings were made of six of the eight sessions that the group ran for. The first stage of the analysis involved making a detailed description of the talk produced in each of these sessions. Then the narrative content of the material that they contained was coded. This allowed the identification of text for detailed analysis which was based on two criteria. First, the text had to form a coherent 'story', that is a narration about an incident in the person's past with an identifiable beginning and end. Narrations are those communicative productions in which there is a story line and in which people present themselves as actors in a drama-these presentations create what have been called 'discursive positions' (Hollway i 984). Narrations can be distinguished from declarations (e.g. Sabat and Harré r 992) in that while both act to preserve aspects of identity, declarations involve the individual giving a report on how things are from his or her point of view, i.e. that person's locus in time and space.

The second criterion that was used to identitfy the text was that these stories should not have a 'meaning' that was immediately obvious to the group leaders. If it was subsequently possible to identify metaphorical aspects to such problematic and challenging talk, then this could be taken as lending the subsequent analysis greater credibility.

The use of these criteria allowed two groups of stories, to be identified 
for analysis. Both have been presented here: in the first, an extended extract from a group session is examined in which two group members each tell a story; the second part of the analysis focuses on a series of retellings of one story in different sessions of the group.

\section{Analysis of the text}

Sequence one: This first group of stories is drawn from near the end of the sixth session in which the group met. The main topic being discussed in this session involved the growing need of group members to depend on others and the feelings that were associated with this for them. The analysis of this sequence of stories is divided into three sections. The first two sections consider those aspects of each of the two stories that can be thought of as metaphorical, while the final section looks at the relationship of the stories to each other and how they may work to establish a social identity.

I.I a The jungle flier. The telling of the story begins as Louise (one of the group leaders) is addressing Tony, a group member, when a second member, Roy (who is sitting on the same line of sight) interprets one of her questions as being addressed to himself and interrupts [I.I.2] (see Appendix One for a description of the notation used):

[I.I.I] Louise: Roy was saying that sometimes he feels that life goes in a cycle, where he uses past experiences, like when he's faced with a situation and it helps him to overcome that situation because he can say 'oh, I've done this before'

Tony: That's right

Louise: Do you look upon it like that?

Tony: Yeah, mm (.) yeah

Louise: Are there any particular situations that you find that happens in, any examples?

Roy: [I.I.2] Yes, there was a case, there was an example in Malay, [I.I.3] we: : had a job to do and we couldn't do it because of the situation of the country

Louise:

Roy:

$$
\left[\begin{array}{l}
\mathrm{mm} \\
{[\text { I.I.4] and the er }}
\end{array}\right.
$$

difficulty of getting through the jungle, thick jungle high grass and things like that. And er I I spotted somebody nearby, and he was talking to somebody else and I went up to him and in fact he was talking about his airplane and what he was going to do at that particular time and so I went up to him and said 'do you want a pilot?' and he said 'yes' (and that was it) although I didn't realise it at the time. [I.I.5] And in fact I assisted in several situations where he had to fly the aircraft out of awkward situations and land it 
somewhere else where it was difficult to get out of again. [1.r.6] So I er put him right on things like that. And I had it organised for a clearing of the jungle path where you were going to land and where we were already fixed at the time to make it safe, to at least making the whole area safe for getting in and out of quickly. And the jungle of course grew while we were there to the point that we used oil and petrol and therefore we cleared it

Rik: $\mathrm{mm}$

Roy: and it came in very useful. And I was busy on that for about a year and a half, approximately. It was the one aircraft and it never let me down I must admit, but er

Rik: So that's something that helps you now?

Roy: That's right

Rik: How does it help you now? how does that help you now?

Roy: [I.I.7] Well if situations that you get into often are very similar to those situations that occurred in Malaya

Rik: Have you been in any recent situations that are similar to that?

Roy: Not recent, no. At the moment, [I.I.8] light aircraft of the type that you fly, they're not very (similar)

Rik: It sounded like in Malaya you were in the right place at the right time Roy: I was, it did occur like that, yes

Rik: Something came up and you could help out

Roy: Well I saw the chance

Rik: $\quad$ and you used it

Roy:

Yes, that's how it was and [I.I.9] I was there for about two or three years roughly, all on the same job and it was most interesting as well as being a lot of work, so I can't grumble really. [I.I.Io] I helped along the way, if you like [laughs] (.) [I.I.I I] At the moment, If I come across the same situation again, but nobody has any airplanes around here [laughs]. That would be useful.

Story-making as metaphor. That Roy's account has a metaphorical quality to it is suggested by two aspects of the story's structure. First, the story is occasioned as a response to a request for examples of occasions from the past which are similar to those of the present. This positioning of the past as an aid to present day understanding is maintained throughout Roy's discourse. The story itself is prefaced by Roy's echoing the group leader's words (I.I.2.) and is continued in an explicit comparison between the present and a past (I.I.3. and I.I.4.). At the end of the story Roy stresses the importance of past memories as ways of understanding and acting on the present (I.I.7.). This is a story of a battle against 'the situation of the country' (I.I.3). Although, at first, the job could not be done, by dint of effort Roy succeeds.

The second suggestion that this story may have a metaphorical quality occurs when the therapist presses Roy to provide a literal 
similarity between the story that he has told and the present day, a similarity which has been used to justify the telling of the story. At this point Roy demonstrates the absurdity of drawing such a literal comparison by twice making a joke of the possibility (I.I.8. and I.I.I I). There is thus a clear sense in which Roy is saying that retelling the past is useful to him in dealing with the present, but that it is not useful to him in a literal sense. The usefulness of this story to Roy may lie in its ability to act as a metaphor through which he can begin to make sense of his present life.

Thus, Roy's reference to 'a case' in Malaya is used as an example of the past informing the present - of life going in a cycle. He details how the 'situation of the country' in which 'thick jungle, high grass' makes it difficult to get through, and he tells how he plays the central role in overcoming such difficulties. In doing this he is able to help and be of assistance to others. He then describes how such recollections of the past are useful to him now that he is in a situation that is similar. The suggestion that has been made here is that the similarity between the past and the present for Roy is a metaphorical rather than a literal one. Elsewhere Roy described living with severe memory loss as a struggle, a battle that he had to fight. It may be that when Roy described thick jungle and high grass which needed to be burnt down but kept growing back, he was symbolically describing some of his own experiences of searching after meaning only to feel it slip away again as he grasped it. It is this act of story-telling within the group that allows Roy to make sense of his current experiences. Meaning is created as part of a communicative act.

I.2 a: Captain Curtis. Immediately after Roy has finished speaking, so Daphne begins to tell her story, a story that she had not told before in the group.

Daphne: [I.2.I] [I think that one of the happiest things that happened to me Rik: UUh huh

Daphne: was during the war. [I.2.2] There was some of our men kept prisoner in Germany, and I was a nanny to Captain Curtis's two little children. And his wife used to say to me 'will you pray (for their release)' and the children were there. And their Daddy was being released at the end of the war, and the moment that we knew that some of the prisoners were being released we had word to say that Captain Curtis was coming home.

Roy: [I.2.3] Oh yes

Daphne: And I went with the children, the two children and he'd never met them and we met him and he said 'is this my children, Nanny?' and I said 'Yes'. And he said 'I'm going to say a prayer now'. I said 'Well wait till you get home', 'No' he said [1.2.4] 'Thank God for having you to look after my boys' and that's something I'll never 
forget. Lord Cambridge's son he was, and he was so proud and after that and he made sure that the two boys (.) (Thank God for the rest of their days). [1.2.5] And there was all these prisoners of war coming home and all meeting their wives and mothers. [1.2.6] And often if I'm down I'll take myself back to that day

Louise: $\mathrm{mm}$ : :

Daphne: and remember the happiness of it all. It was a sad case, he was all thin and he didn't know what to do, [I.2.7] he looked like someone who had really lost his way. And when he told us about what they'd done, what they'd done to him and the hard times they had it was very, very, very sad. [1.2.8] But er: : he made it in the end.

The first piece of evidence to suggest that this story may contain some metaphorical communication, comes from the way in which the story itself is constructed. First Daphne provides a context for the story (I.I.I) in a way that Sacks (I992) describes as a story-preface. The story-teller needs space in which to tell their story and in order to achieve this space makes it clear to others within the group that he or she wishes to tell a story - in so doing the story teller gives up his or her speech turn, inviting others within the group either to accept or reject the request to tell a story. In this case, the intention to tell a story is supported and Daphne is able to introduce the story of Captain Curtis (I.2.2). The story is developed (1.2.3-4) and ends with a summary (I.2.5) after which Daphne reminds us of the reason she initially gave for telling the story (I.2.6). The business of story telling has now been done in that the story has been prefaced, introduced and a course of action followed through, towards an ending which has referred us back to the story preface. However, Daphne continues, adding what we can consider to be a coda (I.2.7-8), almost as if she is explaining to the group the significance of the story in case it has been missed:

It was a sad case, he was all thin and he didn't know what to do, he looked like someone who had really lost his way... and when he told us about what they'd done, what they'd done to him and the hard times they had it was very, very, very sad. But er: : he made it in the end.

This description of Captain Curtis is therefore emphasised by the position of this part of the talk within a coda added at the end of the story. In particular the way in which Captain Curtis was 'all thin ... and looked like someone who had really lost his way' is stressed both by Daphne's use of gestures (for instance when describing how thin Captain Curtis was, she stroked her cheeks with the outside of her hands, leaning forward in the chair as she did so) and by changes in vocal emphasis. Moreover, the story as a whole is new material: Daphne had not told the story of Captain Curtis before this session. In psychotherapy, if new material is produced and at the same time there is a change in non-verbal communication associated with a deepening 
of rapport then this can be taken as significant evidence that the patient has processed the talk of the therapist on an emotional level (e.g. Casement I985; Watts I983). In psychotherapeutic terms, therefore, Daphne's story could be described as acting as a metaphorical communication.

Further evidence for the metaphorical significance of I.2.7-8 comes from Daphne's use of the word 'lost' at other times within the group to describe some of the difficulties associated with memory loss:

a) On three separate occasions she used the phrase 'he's lost' to describe the difficulties that another group member had in articulating his thoughts;

b) Earlier in this sixth session Daphne had described a sense of being 'lost' when she first realised that she could not remember as well as she used to do;

c) During other sessions Daphne spoke of her certainty that she would be 'lost' if she did not have her faith, and of her sense of being 'lost' if her daughter was not with her;

and d) Daphne described her concern over becoming lost when she went out for a walk. She had therefore taken to carrying deliberately a card in her pocket with her name and address on it.

Finally, it is important to remember that Daphne begins her storypreface, without any prompts from the group leaders, immediately after Roy has finished his narration, as if she were responding to this story. Moreover, the way in which Daphne positions herself in her story echoes the position of Roy in his (e.g. both had indispensable skills or qualities valued by others). The perspective of others and their experiences is worked into the accounts as the narrator moves between different points of view. Viney (1993) suggests that the creation of stories that are similar to each other enables speakers to communicate to each other that they have understood something of what the other has been saying. Indeed while Daphne is telling her story, Roy looks at her, she at him and he seems to support her telling of the story through his posture and comments.

If, then, we allow Daphne's story of Captain Curtis to stand, in part as a metaphorical communication, then we need to look for clues as to its significance from other themes within Daphne's discourse. The story of Captain Curtis has strong Christian overtones of redemption and faith: here is a man who experienced hard times which were very sad, but who 'made it in the end' (I.2.8). In being released from captivity and returning to a family that he does not recognise, so Captain Curtis gives thanks to God for the care of the Nanny for his children (I.2.4).

This theme of redemption is echoed in other aspects of Daphne's talk in this group. For instance at the end of every session, Roy was asked 
if he would mind playing the piano. Roy in turn asked the group what they would like him to play, and every week Daphne asked for the same song, 'We'll meet again'. What lends the choice of this song particular poignancy is not simply its place as an icon of British War songs but that in our final session, Daphne described her faith as sustaining her against the knowledge of her future death because she knew that someday 'we'll meet again'.

Social identities. As well as understanding these stories in terms of their metaphorical communication, they can also be understood as acting to establish a sense of social identity within the group. First of all, this talk occurs within the context of a discussion of the need to depend on others. In contrast to their previous talk in this session, where both Roy and Daphne had described the help that they received from carers and the Day Hospital staff, in these accounts both speakers emphasised past times when it was they who had helped others. Thus Roy says in I . I.5-6: 'I assisted in several situations ... I helped along the way if you like... I er put him right on things like that', while Daphne described Captain Curtis as having said to her in I.2.4: 'Thank God for having you to look after my boys'.

Buchanan and Middleton (I994) have described this as a process whereby individuals argue their entitlement to care. In this sense, one function that these accounts may serve is that they allow Daphne and Roy to establish within the group that there have been other times when it is they who have been depended upon by others. Thus elsewhere Daphne commented that 'I tell myself that God's rewarding me now for what I did during the war days'. On another occasion she recounted how, as a Nurse, she had helped a blinded airman, referencing this account by saying that 'Now I understand what he went through'. This was also an important process for Roy who comments shortly after Daphne had ended her story of Captain Curtis :

[1.3] You get the occasional period when you can't be helped with anything at all, and you just stop feeling useful. And they [memories] come along almost automatically, they're almost bound to because you can't think of anything else. It's not all life.

Roy seems to be saying at this point that his present-day sense of not being useful was counterbalanced by his ability to reconstruct a past in which it was he who was depended upon by others. This was a time when he was, indeed, useful.

As well as serving to argue their entitlement for care, these accounts locate Roy and Daphne within a social past and as such they are reminders for the individuals of their own resources (Buchanan and Middleton i 995). Not only are they elderly recipients of care, but Roy 
has also been a trouble-shooting pilot, Daphne a Nanny. Moreover, in this work they were being of help to prestigious social groupings (BP, the aristocracy). As such this talk allows Roy and Daphne to construct an identity for themselves away from their position as Day Hospital patients with a diagnosis of Alzheimer's Disease.

Sequence two: the Unity Mitford stories. ${ }^{1}$ The second part of this paper focuses upon the sequence of stories told by Daphne about Unity Mitford. The sequence of stories of Unity Mitford act, in part, as a description of a personal fight against overwhelming odds and as such can be understood as a metaphorical account of the experience of dementia. Each retelling of the story differs from those that precede and succeed it such that at times elements of these different versions of the story contradict one another. These changes allow the social and metaphorical functions to which the story can be put to develop. Thus, a recurring element of these stories is of how Daphne hit Unity Mitford. Each retelling of the story involves changes to the narrative surrounding these events. Thus Daphne's hitting of Unity Mitford is warranted at different times by being told within the context of a parent's need to chastise children or the need to save Unity from herself. On another telling the hitting of Unity is left out and finally it is covered over through the use of humour. These inconsistencies in the accounts do not reflect underlying changes in her 'cognitive state' rather there is interactive consistency in the variability displayed in the different accounts.

Extract 2.I is taken from the first week that the group met. At this point the story is simply one of a number of separate stories in which Daphne describes her life from her childhood in Devon, to her career in service, and then her own marriage and family. As such these stories can be understood as having a common function of establishing Daphne's identity within the group.

[2.I.I] Daphne:... and I ended up with Lord Cambridge's daughter, the one that was Hitler's young lady, now what was her name now? I can't remember how, but I used to walk her through London (.) Unity Mitford that was her name. I used to walk her through London and all of a sudden she'd look at me and people in the street and she'd shout 'Heil Hitler, Heil Hitler'. [2.I.2] And I'd have to hit her which I was told to do and I'd say 'Now we'll go no further, we're walking back' and we'd go back home.

Daphne warrants her own hitting of Unity as something which she was told to do. Later in this session Daphne described how correcting a child was justified as children need to learn to tell the truth, not lies. Unless they learnt this lesson, children would never be happy, and being happy was the main reason for living. While describing two 
occasions in which she has hit other people, Daphne distances herself from her actions, implicitly recognising that such acts could be recognised as unjustifiable. These acts of hitting are not the actions of a bad woman, she suggests, but of a considerate mother and a Nanny who was simply doing as she was told (2.I.2). By providing the warranting that she does, Daphne implies that if she had not hit either Unity or her daughter, then she would have been negligent.

In the second session, when the general theme being discussed was that of 'friends', Daphne told a story about Unity Mitford on two occasions.

[2.2.1] Lesley: Has anyone else found that they've had good friends but not been able to keep up with them?

Daphne: Yes, I have, because during the war I was nursing. I'd take different people out for walks in the street. Unity Mitford was one, she was Hitler's young lady, wasn't she? I'd take her walks in the street and people, she'd say 'Heil Hitler' [2.2.2] and I was given orders to hit her across the face when she did that. And somebody came up and said 'what did you do that for? because she shouted Heil Hitler?' So I said 'Hitler's our enemy [2.2.3] and I don't want anything to do with him and I don't want Unity to have anything to do with him'. [2.2.4] So I used, they said 'come to our meeting where we've got two places'. So I took Unity with me and after about five meetings she come to me, caught hold of my hands and gave me a kiss and said 'thank you, you've saved me'. And I think of that many a time when I'm feeling down. I take myself back to those days and saving her.

In this telling of the story Daphne once again represents her hitting of Unity both as something that she was forced into (2.2.2.) and as something that she did through kindness (2.2.3.). At the same time Unity is positioned as a friend, both by Daphne's telling of the story in response to the therapist's question and by the use of her Christian name. Yet the notion of friendship suggests an equality of positions within the relationship, and this is difficult to balance with the act of hitting Unity. As a way of resolving the conflict between these two aspects of the account, Daphne later further justifies her actions by recounting how Unity recognised that Daphne had saved her [2.2.4]. Later in this session, Daphne returns to this story when another group member challenges her by suggesting that the effects on her of having to move jobs as a Nurse cannot have been too unpleasant:

[2.3.I] Daphne... Unity Mitford, when she was brought back to England she came (.) children's Nanny (.) and was the husband of (.) well, anyway, she came back the next day and I was used to take her out. When her dad came get her, because of course, Unity was Hitler's girlfriend, and when her dad came to take her she put her arms around me and sobbed her heart out and I did too. I felt as if I'd lost 
some something belonging to me. And her father asked if I'd go to Wales. And I said I can't go to Wales.

Lesley: So even though you had a very hard relationship to start with/

Daphne: /Yes, I really looked upon her as a sister because it was all 'Heil Hitler, Heil Hitler'. And I had to hit her on the face and all sorts. Doctor told me what to do. And I felt I got her better. And I thought, 'we've gone through all that now she's going away'. It's an experience when you're younger nobody do cannot explain. But still I often think about her... Losing a friend, it's like being cut in two...

This version of the story emphasises a number of the themes described above. In addition, however, the sense of loss at losing something belonging to her, implicit in 2.2, is developed through the introduction of new material. Whereas before Daphne has described the possibility of being saved, so in 2.3. I she talks of the reality of loss. Where there is hope, so too is there anger and sadness. Indeed Daphne continues talking on this theme, describing a relative of hers who committed suicide. She says that it makes her both very angry and very sad to think that nobody bothered to help her. Nevertheless, she hopes that her relative has been accepted into heaven. By placing these two stories in juxtaposition, so Daphne provides two similar examples: one where she has saved another person, and the second of a time where nobody, including herself, had been able to act.

The session in week three was not recorded due to a technical fault. In week four, Daphne once again tells a version of the Unity Mitford story

[2.4.I] Daphne:...Well, during the war, when the war was over, Unity Mitford, I expect that you've heard of her, well she came over from Germany or wherever she was, and where I was a children's Nanny, she was a friend of Unity's long before the war. And she brought her back to England and to London then. And Unity came down to me and she was talking one day and [2.4.2] I said 'well have you been outside and walked around in London?'. She said 'No, I'm afraid'. I said 'why?' She said 'because I loved Hitler and I shouted "Heil Hitler"'. So I said 'on condition that you will do as I ask you if I take you out and not call out Hitler, I will take you out'. And I did that, I asked permission from the lady that I was children's nanny and she said 'Yes Nanny, and you take the two boys with you as well and then she can talk to them as well'. And I did it, and she'd go along and she'd say 'Heil Hitler' [2.4.3] and the little boys would say 'it's Heil mummy, not Hitler' and [2.4.4] I got her out of saying that. [2.4.5] And afterwards she put her arms around me and she said 'can I thank you?' she said 'I thought I was in love with Hitler and I've proved myself wrong'. And I've never forgotten that and I think of her everyday and pray that God will help her, that is if she's still alive. But it's sad really when you've lived through the war because when you're living through the war you get all these sorts of things. 
There are a number of important differences between the version of the story that is recounted here and that was described before. First of all Daphne plays a much more active part in the story: for instance it is her suggestion that she escort Unity outside the home [2.4.2]. Secondly, there is no mention of Daphne hitting Unity, rather the boys tell her off. These changes are consistent with each other in that as Daphne positions herself more actively within the story so she could no longer represent herself as also being constrained by higher authority, as the faithful Nanny acting on the orders of another wiser person. Finally, Daphne's depiction of herself as Unity's saviour is fleshed out: she has faith enough in Unity to befriend her; it is Daphne that gets Unity 'out of saying that' [2.4.4]; and through her actions, Daphne helps Unity to prove to herself that she was wrong to think that she loved Hitler $[2.4 \cdot 5]$. This story still invokes sadness, but the sadness is not explicitly linked to the loss of Unity as a friend.

Much of the session in week five is again missing. However, in the ten minutes of dialogue that is available, Daphne once again taîks about Unity. This occurs within the context of a discussion of memory problems experienced by members of the group. Daphne describes how frightening it is to be unable to remember things ('it's a horrible, horrible feeling that I can't explain, all of a sudden you can't remember things'). She feels that God helps her and she also thinks about the war. These memories are reassuring for her and she talks of a pilot whom she nursed with memory problems. She used to take him for walks and remind him of things: 'now that I'm losing mine I look back and I think, well I'm sharing it with him'.

[2.5.I] Daphne: Yes, Unity Mitford, I can remember her as if she was sitting here now, 'cos I used to walk her through London. She was Hitler's young lady, [2.5.2] wicked girl. She was God's child. When it comes back. [2.5.3] You see I think, you die, I do. Sometimes I've got to sit there and just think, or close my eyes until it comes back. Then I'm all right and off I go again. But then I'm getting older ... [2.5.4] Sometimes it feels like a bit of a battle. It is a battle but I won't give in. The soldiers, sailors and airmen during the war, they didn't give in. I always say God's on one shoulder and my husband's on the other shoulder, so you'll never walk alone.

From this extract it is clear that this remembering of Unity is an active process that Daphne uses as she struggles against the experience of Alzheimer's disease (2.5.3-4). What makes this story so powerful is the symbolism of the triumph of hope over despair that the saving of Unity from herself represents (seen in the juxtaposition in 2.5 .2 of 'wicked girl' and 'she was God's child'). The story is positioned within this context in Daphne's metacognitive depiction of herself as fighting 
a battle (2.5.4). The recounting of stories such as that of Unity Mitford in which an evil person can be saved through faith is just as much part of this fight as is Daphne's deliberate carrying of a card with her name and address written on it. This meta-cognitive depiction of the 'memory' of Unity Mitford as a resource to present day understanding and sense-making is continued by Daphne's representation of Unity Mitford in week six:

[2.6. I] Daphne: Now I'm on my own, I can sit back, sit down and look back on my life especially the war days when Unity Mitford, she was Hitler's young lady, wasn't she?

Rik: Does it help you to think back over your past//

Daphne: //Yes because [2.6.2] it makes me realise what the war was all about (... the people to look after) and Unity Mitford was brought back and I was the one, where I worked as a children's nanny and the lady there brought Unity Mitford back to England and I was the one who used to walk her through London. And there she would be shouting out 'Heil Hitler' and of course each time I'd hit her across the face (which I was taught to do). And I often think back to that day and think 'well why should she say that about that horrible man?' And I used to say 'Hitler, I'd shoot him', 'no, no he's a lovely man, a lovely man'. And I'd say 'so why have you come home, then why are we fighting this way?' and she could never answer.

For Daphne understanding 'what the war was all about' [2.6.2] is not an academic exercise. It gains its significance from the symbolic relationship between the remembered war and her current experiences. It is not simply that an understanding of the past informs the present by providing a metaphor (living with dementia is like fighting a battle) but that the past is framed through the present. Recollections of the past are recounted, remembered and re-invented through current experiences. Past events are invested with new meanings and acquire new significance in the light of current struggles. Daphne uses the voices of Captain Curtis, Unity Mitford and the pilot with memory problems as a way of commenting on her own predicament.

In the final week of the group, Daphne again returns to Unity Mitford:

[2.8.I] Daphne: I used to walk through the streets when she [Unity Mitford] came around (before she met Hitler) and she'd shout out 'Hitler' and [2.8.2] I'd smack her across the face and [2.8.3] people going past 'give her another one! give her a kick up the bottom!' [laughter] [2.8.4] oh, it was wrong I'm sure (.) (forgive her one day)

This account departs from the others detailed above in that Daphne describes hitting Unity but neither positions herself as her friend and saviour nor as being constrained by authority. Indeed Daphne doesn't 
simply 'hit' Unity as she had described herself doing before, instead she'd 'smack her across the face' [2.8.2] while passers by are reported not simply as witnesses to the event occasioning the need for justification [2.2.2-3] but as encouraging the violence [2.8.3]. At the same time the moral restraint on action which necessitated the talk of hitting Unity being warranted $[2 . \mathrm{I}, 2.2 .2,2.5,2.6 .2]$ is also recognised $(2.8 .4$ : 'oh, it was wrong, I'm sure'). Daphne's use of humour can be seen as a means of covering a clash between these two opposing discourses (Harper I 994, quoting Gilbert and Mulkay i 984). This allows the conflict to be acknowledged whilst obviating the need for it to be resolved.

Metaphor and symbolism in talk about Unity Mitford. Unity Mitford is repeatedly characterised as Hitler's young lady or his girlfriend. Yet despite their relationship, she is 'saved' through her relationship with Daphne. The strong Christian symbolism of this redemption is plain just as Unity believed in Daphne and was saved, so Daphne will believe in those around her now. Yet at the same time there is sadness and anger within these stories, and if there is eventual redemption, then there is initial uncertainty. The positioning of characters within these stories allows this struggle to be experienced vicariously, as a process happening to Unity Mitford in the past rather than being directly recounted as involving Daphne in the present. This story, then, achieves the dual functions for Daphne of expressing something about her hopes and fears for herself, while also removing her from the loss, uncertainty and terror involved in her experience of dementia.

Daphne was able to use the group as a forum within which she was able to describe, and make sense of, aspects of her own, personal, experience of dementia (e.g. 2.5.3). When she does so she emphasises how frightening this process is (e.g. 'it's a horrible, horrible feeling that I can't explain, all of a sudden you can't remember things'). In talking about her current life, so Daphne explicitly draws a parallel with battles in the past $(2.5 \cdot 4)$. This talk acts to place the present with a framework through which it can be understood and within which the future can be planned and potential threats negotiated. For Daphne, as for many others, understanding the present involves recreating a past in which she had to struggle or battle. As Mair has described, the telling of a story involves not just speaking for but speaking against a terrible unknown:

In every story there is a fight for survival, there is a politics of assertion and rejection...Each story is a claim to existence set against other known and partly sensed claims. It is also set against the terrible unknown, the potential claims that we do not own, do not understand and have not anticipated. (1988: i 32, original emphasis). 


\section{Discussion}

The importance of talk organised into a story or series of stories within psychology and psychotherapy has been described elsewhere (e.g. Gergen and Kaye ı992; Mair ı 988, r989; Sacks ı 992; Sarbin I986; Shotter i 993; Viney I993). In telling a story here about the stories that I have been told, I am aware that I have offered only a partial and particular version. Similarly I am aware that, by focusing on story telling about the past, on reminiscence, other aspects of the discourse produced within the group have been passed over. It is not my intention to argue that this is the only way in which the talk produced in this group could be understood, nor that this analysis is any more 'truthful' than any other. Rather, I would argue that it is more useful to understand the talk of older people with dementia through this framework.

The dominant story that is told about people with dementia is that their talk is meaningless, their memories are defective, and that their reminiscences are of little importance in the planning of care (Kitwood I990 $a$ ). It has been argued here that there are other stories to be told about the talk produced by people with dementia if we can only allow ourselves to listen to the poetical, the metaphorical aspects of language. For Roy and Daphne it is as if aspects of the experience of dementia were like creating a landing strip in the jungle, only for the jungle continually to regrow; being a prisoner of war who had been lost and who is then found after much sadness; or a war between good and evil.

However, the use of symbolism as a means of communicating emotional responses is not unproblematic. First, the use of metaphors can both define and constrain meaning. Speakers within a group need to be able to alter their use of metaphorical language to accommodate the language use of others if a shared social meaning is to develop (Owen I985). Secondly, those around the speaker need to be able to understand the way in which his or her talk acts as a metaphor. As we have seen with Roy and Daphne, a major part of this ability to decipher meaning depends upon observers being able to interpret talk or gesture by understanding the context within which that talk is produced. It may be that as a result of cognitive changes and alterations in the social psychological environment the talk of individuals with dementia is in some way dislocated from their environment. This may be a central reason for the frequent use of the term 'confused' to describe the behaviour or language of many people suffering from dementia. Sabat and Harré have argued that the verbal adaptations that Alzheimer's Disease sufferers need to make in order to 
maintain their selfhood can be represented as symptoms of the disease process itself:

... If such behaviour is founded on story lines that paint the sufferer as inadequate, confused, helpless etc. then that person will be so positioned and will have his or her behaviour interpreted by others in such a way as to confirm the initial story line and positioning. The ultimate result of such a situation is the fencing off of the sufferer so that no adequate $\operatorname{self}(2)$ can be constructed. Perhaps it is not stretching the point too far to refer to such a situation as a species of self-fulfilling hypothesis (1992:444-46o).

Emotional symbols, then, can act as communications only so long as others are able to interpret them. In addition they can also act as a means through which emotions can be understood or given form. The use of symbols within talk lends a first form to what are otherwise only vaguely or partially ordered feelings and activities (Shotter I 993). The telling of stories, of extended and connected symbols permits an individual 'to tell it like it is' (Mair i g88).

It has been argued elsewhere that our representations of 'dementia' have been organised in a way that allows us to hear the voices of dementia sufferers without having to listen to what they are telling us (Gubrium i 986). For instance the loss of brain cells has become almost synonymous with a loss of mind (Fertziger I988). Thus, an overconcern with the form of memory, has prevented us from addressing its function. Similarly, debating the nature of the presumed internal conflicts that give rise to reminiscence has prevented researchers from examining what it is that people do when they talk about the past. A social constructionist approach bypasses issues to do with the nature of internal states and consequently makes no distinction between psychotherapeutic work with people with or without a dementing illness. It forces us to concentrate on how meaning is created within a social context. Attending to such meaning is inherently painful, as it forces us to acknowledge issues to do with loss, fear and isolation. However, without doing this, we will never be able to provide a true psychology of dementia, we will simply be producing a psychological commentary on the psychiatry of dementia.

\section{Acknowledgement}

This paper is based on work that was undertaken while I worked for Bath Mental Health Care (NHS) Trust. I would like to thank Andrea Hirons, Lesley Milner, Louise Bull, Laura Sutton, Christine Medway, Jane Fossey and Elizabeth Barnet for their help in the preparation of this paper. 


\section{NOTES}

I The names of clients and those people referred to by clients which have been used in this paper have been changed with the exception of Unity Mitford's. It was felt that her relationship with Hitler was already public knowledge and that to have substituted a pseudonym would have distracted from the explanatory power of the arguments presented in this paper.

\section{Appendix}

The notation used in this paper was as follows:

- Round brackets enclosing a word or part of a sentence denotes that material in the brackets was either inaudible or there was doubt about its accuracy.

- Numbers within square brackets indicates that they are there to help identify material referred to in the text. - The inclusion of text within square brackets is for clarification of meaning.

- A full stop in a bracket indicates a pause, e.g. 'oh, it was wrong I'm sure (.)'

- One or more colons indicates an extension of the preceding vowel sound, e.g. 'er: :'.

- Extended square brackets mark overlap between the utterances of different speakers.

- Use of italics indicates that the speaker added stress to the word.

\section{References}

Anderson, H. and Goolishan, H. I992. The client is the expert: a not knowing approach to therapy. In Gergen, K. J. and McNamee, S. (eds) The Social Construction of the Psychotherapeutic Process. Sage, London.

Babbins, L. I 988. Conceptual analysis of validation therapy. International Fournal of Ageing and Human Development, 26 (3), I6 1 - I 68.

Bleathman, C. and Morton, I. ig88. Validation therapy with the demented elderly. Fournal of Advanced Nursing, 13, 5I I-5I4.

Bleathman, C. and Morton, I. ig9i. Validation therapy with the demented elderly. Nursing Standard, July 3I, 5, 45 .

Bleathman, C. and Morton, I. I 992. Validation therapy: extracts from 20 groups with dementia sufferers. Fournal of Advanced Nursing, 17, 658-666.

Buchanan, K. and Middleton, D. i 993. Discursively formulating the significance of reminiscence in later life. In Coupland, N. and Nussbaum, J. F. (eds) Discourse and Lifespan Development. Sage, London.

Buchanan, K. and Middleton, D. I994. Reminiscence reviewed: a discourse analytic perspective. In Bornat, J. (ed.) Reminiscence Reviewed: Perspectives, Evaluations, Achievements. OUP, Buckingham.

Buchanan, K. and Middleton, D. i 995. Voices of experience: talk, identity and membership in reminiscence groups. Ageing and Society, 15, 457-49I. 
Casement, P. 1985. On Learning from the Patient. Tavistock, London.

Coleman, P. I994. Reminiscence within the study of ageing: the social significance of story. In Bornat, J. (ed.) Reminiscence Reviewed: Perspectives, Evaluations, Achievements. OUP, Buckingham.

Feil, N. 1990. Validation: The Feil Method. Edward Feil Productions, Cleveland.

Feil, N. I992. Validation therapy. Geriatric Nursing, May/June, I29-133.

Feil, N. I 993. The Validation Breakthrough: Simple Techniques for Communicating with People with 'Alzheimer's-Type Dementia'. Health Promotions Inc., Baltimore.

Fertziger, A. P. I988. Alzheimer's Disease and the mind-brain problem. In Mayeux, R., Gurland, B., Barrett, V., Kutscher, A., Cote, L. and Putter, Z. (eds) Alzheimer's Disease and Related Disorders: Psychosocial Issues for the Patient, Family, Staff and Community. Charles C. Thomas, Springfield, Illinois.

Gergen, K. and Kaye, J. I992. Beyond narrative in the negotiation of therapeutic meaning. In McNamee, S. and Gergen, K. (eds) The Social Construction of the Psychotherapeutic Process. Sage, London.

Gubrium, J. I 986. Old-timer's and Alzheimer's: the Descriptive Organization of Senility. Jai Press Inc., Connecticut.

Haight, B. K. and Bahr, R. T. I984. The therapeutic role of life review. Academic Psychology Bulletin, 6 (3), 287-299.

Harper, D. J. I 994. The professional construction of 'paranoia' and the discursive use of diagnostic criteria. British Fournal of Medical Psychology, 67, I3I-I 43.

Hoffman, L. I 988. Like a friendly editor: an interview with Lynn Hoffman. Networker, September/October.

Hollway, W. I984. Gender differences and the production of subjectivity. In Henriques, J., Holloway, W., Urwin, C., Venn, C. and Walkerdine, V. (eds) Changing the Subject. Methuen, London.

Kitwood, T. ig9o a. Psychotherapy and dementia. BPS Psychotherapy Section Neresletter, $8,4^{0}-56$.

Kitwood, T. I $990 b$. The dialectics of dementia: with particular reference to Alzheimer's disease. Ageing and Society, ro, i 77-196.

Kitwood, T. 1993. Person and process in dementia. International Fournal of Geriatric Psychology, 8, 54I-545.

Kitwood, T. and Bredin, K. I992. Towards a theory of dementia care: personhood and well-being. Ageing and Society, 12, 269-287.

Lakoff, G. and Johnson, M. I980. Metaphors We Live by. University of Chicago Press, Chicago.

Mair, M. 1988. Psychology as storytelling. International Fournal of Personal Construct Psychology, I, I25-137.

Mair, M. I989. Between Psychology and Psychotherapy: a Poetics of Experience. Routledge, London.

Mills, M. and Coleman, P. 1994. Nostalgic memories in dementia - a case study. International Journal of Aging and Human Development, 38 (3), 203-2 I 9.

Owen, W. F. I985. Metaphor analysis of cohesiveness in small discussion groups. Small Group Behaviour, I6 (3), 4I 5-424.

Potter, J. and Wetherell, M. I987. Discourse and Social Psychology: Beyond Attitudes and Behaviour. Sage, London.

Radley, A. I990. Artifacts, memory and a sense of the past. In Middleton, D. and Edwards, D. Collective Remembering. Sage, London.

Sabat, S. R. and Harré, R. I992. The construction and deconstruction of self in Alzheimer's disease. Ageing and Society, 12, 443-46r.

Sacks, H. I992. Lectures on Conversation, Volume II. Blackwell, Oxford. 


\section{Rik Cheston}

Sarbin, T. R. I986. The narrative as a root metaphor for psychology. In Sarbin,

T. R. (ed.) Narrative Psychology : the Storied Nature of Human Conduct. Praeger, New York.

Shotter, J. I g86. A sense of place: Vico and the social production of social identities.

British Fournal of Social Psychology, 25, I99-2 I I.

Shotter, J. 1993. Conversational realities: Constructing Life Through Language. Sage, London.

Sperlinger, D. and McAuslane, L. 1994. Listening to users of services for people with dementia. Clinical Psychology Forum, 73, 2-4.

Stokes, G. and Goudie, F. I99o. Counseling confused elderly people. In Stokes, G. and Goudie, F. Working with Dementia. Bicester, Winslow.

Sutton, L. 1994. What is it to lose one's mind? Paper presented at the roth International Conference of Alzheimer's Disease International, University of Edinburgh.

Sutton, L. and Fincham, F. 1994. Client's perspectives. BPS Psychology Special Interest Group for the Elderly Newesletter, 49, I 2-I 5 .

van Langenhove, L. and Harré, R. I993. Positioning and autobiography: telling your life. In Coupland, N. and Nussbaum, J. F. op. cit.

Verwoerdt, A. I981. Individual psychotherapy in senile dementia. In Miller, N. and Cohen, G. (eds) Clinical Aspects of Alzheimer's Disease and Senile Dementia, Raven Press: New York.

Viney, L. L. 1993. Life Stories: Personal Construct Therapy with the Elderly. Wiley, Chichester.

Watts, F. I 983. Strategies of clinical listening. British Fournal of Medical Psychology, 56, I I $3-$ I 23 .

Yale, R. I 99 I. A Guide to facilitating Support Groups for Newly Diagnosed Alzheimer's Patients. The Alzheimer's Association, Greater San Francisco Bay Area.

Yalom, I. D. 1975. The Theory and Practice of Group Psychotherapy (2nd ed.). Basic Books, New York.

Article accepted 24 October 1995 